\title{
STRATEGI IMPLEMENTASI KURIKULUM: SUATU KAJIAN PERSPEKTIF TEORI DI SEKOLAH DASAR
}

\section{H. Sudirman ${ }^{1}$}

\begin{abstract}
Core schools deserve to be models from other schools, especially in terms of curriculum implementation. This paper is a descriptive which aims to describe the curriculum implementation process that should be done in elementary school. The Curriculum of 2013 as a form of educational innovation in Indonesia requires various adjustments, especially in the process of implementation. The right curriculum implementation strategy in the presence of an innovation curriculum is teacher oriented. There are three effective teacher-oriented strategies, namely adjusting the mindset, developing new cultures in school and developing the curriculum. The strategy of the O'Mallay and Chamot Model learning process and the Oxford Model Strategy is very feasible to apply in elementary schools with reference to the 2013 Curriculum. Teachers must be able to apply effective, varied and adaptive learning strategies in order to develop students' learning strategies maximally.
\end{abstract}

Keywords: Strategy, implementation, curriculum, learning, innovative.

\section{PENDAHULUAN}

Kurikulum 2013 yang disingkat K-13 merupakan perwujudan dari upaya pemerintah untuk terus melakukan penyesuaian kurikulum. telah mengamanatkan bahwa kurikulum pada semua jenjang dan jenis pendidikan dikembangkan dengan prinsip diversifikasi sesuai dengan satuan pendidikan, potensi daerah, dan peserta didik. ${ }^{2}$ Dalam rangka itulah, maka peranan guru menjadi sangat penting. Guru adalah bagian utama darisistem pembelajaran yang berperan mengembangkan kurikulum. sesuai amanat undang-undang. Kurikulum hendaknya relevan dengan tuntutan, kebutuhan, dan perkembangan masyarakat. ${ }^{32}$

\footnotetext{
${ }^{1}$ Dosen FIP- UNM Makassar UPP-PGSD Bone

${ }^{2}$ Undang-Undang No. 20 Tahun 2003. Pasal 36 Ayat 2. h.19.

${ }^{3}$ Nana Syaodih Sukmadinata, Pengembangan Kurikulum: Teori dan Praktek. Cet. ke-13. (Bandung: Remaja Rosdakarya, 2010) h. 150.
} 
Kurikulum yang mencerminkan kualitas peserta didik yang diharapkan, dapat menjadi arena atau race yang efektif untuk membawa perilaku peserta didik menjadi lebih baik.Isi kurikulumbukan hanya menyiapkan anak untuk kehidupannya sekarang, tetapi juga masa datang. Prinsip kontinuitas kurikulum ini hendaknya disertai dengan perubahan pemahaman isi dan cara bertindak seorang guru.Guru sedapatmungkin tidak mempertahankan pedagogi konvensional dalam menerapkan isu-isu inovatif yang muncul bersamaan dengan perubahan kurikulum yang terjadi.Pembaruan yang terjadi diharapkan diikuti oleh perubahan tindakan guru yang sesuai dengan tuntutan pembaruan baik dalam perilaku maupun kepercayaan yang muncul dari perilaku tersebut.

Isu-isu inovatif yang perlu dipahami oleh guru adalah perubahan peranan guru dalam proses pembelajaran.Antara lain perubahan peranan sebagai transmiter menjadi fasilitator, dari teacher centered menjadi student centered, pergeseran dari content-based curriculum menjadi competency-based curriculum. ${ }^{4}$ Perubahan peranan tersebut bagi guru menjadi strategi prasyarat untuk dapat mengimplementasikan kurikulum dengan segala dimensi perubahannya pula. Dalam perspektif ini, pelaksanaannya tentu akan menjadi lebih efektif apabila didukung oleh penerapan prinsip keizendalam proses pembelajaran.

Harapan pemerintah dengan adanya sekolah inti adalah sekolah inti mampu menerapkan strategi efektif dalam mengimplementasi kurikulum yang berbeda dengan sekolah bukaninti. Siapa pun yang berpandangan positif tentu tidak akansetuju,apabila sekolah inti hanya menampakkan keindahan fisik yang menakjubkan, sementara sekolah tersebut mengalami masalah serius dari aspek pelaksanaan kurikulum dan gagal dari segi pencapaian tujuan. Untuk melaksanakan kurikulum dengan berhasil guna, guru hendaknya terlebih dahulu memahami dan menghayati falsafah dan tujuan kurikulum, struktur, dan organisasi kurikulum serta mata-mata pelajaran. ${ }^{5}$

Sekolah dapat disebut sekolahinti apabila sekolah itu berhasil dalam mengelola orang, mengelola organisasi dan mengelola perubahan.Salah satu pengelolaan perubahan itu adalah perubahan kurikulum. Perubahan tersebut tampak pada sekolah yang pelaksanaan kurikulumnya memberi kesempatan belajar yang memadai kepada peserta didik, terkoordinasi, pengajaran aktif, fokus dan misi pendidikan sekolah yang jelas.

\footnotetext{
${ }^{4}$ K.A.Toh et al. Developing curriculum in Singapore: teacher-academic Partnerships. Journal of Curirculum Studies. 28 (6) 1996. h. 683-697.

${ }^{5}$ Mook Soon Sang Falsafah Pendidikan, Kurikulum dan Profesionalismne Keguruan. (Selangor: Penerbitan Multimedia SDN.BHD, 2010), h.170.
} 


\section{PEMBAHASAN}

\section{Strategi Implementasi Kurikulum}

Dalam tulisan ini, strategi diartikan sebagai rancangan yang memuat rangkaian kegiatan yang didesain untuk mencapai tujuan pendidikan tertentu. Strategi implementasi kurikulum berarti rancangan kegiatan untuk melaksanakan kurikulum secara efektif dan efisien. Implementasi kurikulum berarti penerapan kurikulum dalam proses pembelajaran yang dapat memberi pengaruh terhadap perubahan perilaku peserta didik. Mengimplementasikan kurikulum secara efektif, diperlukan kesiapan guru, baik kesiapan administrasi pembelajaran, maupun kesiapan mental. Sebab, dalam implementasi kurikulum sangat mungkin terjadi munculnya perbedaan antara perencanaan dengan realitasifatnya lokal dan kontekstual.

Sebuah kurikulum yang baru diberlakukan menyebabkan kepercayaan profesional guru berkurang dan kemampuan profesional melemah. Guru memerlukan berbagai penyesuaian baik penyesuaian tentang konsep maupun implementasinya. ${ }^{6}$ Strategi implementasi kurikulumhendaknya diarahkan kepada peningkatan kemampuan guru sebagai manusia kunci (key person) di dalam ruang kelas.

Strategi implementasi kurikulum berorioentasi guru antara lain:

a. Mengubah mind set guru dari paradigma konvensional yang statis ke paradigma modern yang dinamis. Perubahanmind set guru dilakukan untuk mengimbangi pengaruh teknologi komunikasi dan informasi yang demikian hebat yang akhir-akhir ini dikenal dengan era industri 4.0. Hal ini penting untuk menata langkah meningkatkan kualitas pembelajaran sesuai dengan keperluan dan tuntutan zaman modern ini.

Guru masa kini adalah guru yang dapat menyesuakan diri dengan kondisi kekinian tanpa mengganggu jati diri sebagai masyarakat yang berbudaya. Guru perlu ditantang untuk mengubah paradigma sehingga kesempatan mereka terbuka untuk berkontribusi lebih baik dalam profesinya. ${ }^{7}$ Beberapa paradigma guru terhadap profesinya yang sering menjadi penghambat dalam pencapaian hasil secara komprehensif yaitu (a) pekerjaan guru adalah mengajar saja, bukan mendidik, (b) guru lebih memahami dari pada peserta

\footnotetext{
${ }^{6}$ Jian Wang dan Lynn W. Paine,. Learning to teach mandated curriculum and public examination of teaching as contexts. Journal homepage: 2002. h.76.

${ }^{7}$ Thorburn,Seizing the Moment: Improving curriculum and pedagogy prospects for physical education in Scotland.Symposium Journal.2007.h.49.
} 
didik, (c) guru menjadi satu-satunya sumber belajar dan (d) mengutamakanmetodemengajar ceramah. Apabila prinsip paradigma tersebut masih mewarnai pembelajaran hingga dewasa ini, maka implementasi kurikulum yang sesungguhnya akan susah dicapai. Oleh karena itu, revolusioner mind set guru mesti dilakukan untuk melayani mainstream perubahan yang terus melaju.

b. Membentuk budaya (kultur) baru di lingkungan sekolah

Membangun budaya kaitannya dengan implementasi kurikulum adalah sejumlah perilaku yang disepakati bersama sebagai identitas guru pada suatu sekolah. Kesepakatan tersebut kemudiandiiringi dengan menghadirkan komitmen yang konsisten untuk melaksanakannya. Komitmen guru terhadap sekolah yang tinggidan kerja sama yang baik antarguru merupakan ciri bahwa sekolah tersebut efektif. ${ }^{8}$

Budaya suatu organisasi (sekolah) adalah sangat penting karena mempunyai dampak yang besar terhadap efektivitas dan produktivitas suatu sekolah. Organisasi sekolah yang sukses mempunyai tujuan yang jelas lagi kuat, berlandaskan misi dan nilai yang telah disepakati bersama, norma-norma perilaku, kerjasama dan mempunyai produktivitas dan pencapaian hasil yang tinggi. Budaya dapat berperanan sebagai rekonstruksi pola pikir guru untuk maju dan berkembang menurut tuntutan zaman. Suatu keniscayaan apabila mind set guru telah mengalami perubahan ke arah yang dikehendaki, maka dapat membentuk budaya-budaya baru di lingkungan sekolah. Dengan demikian, apapun dan bagaimanapun bentuk implementasi kurikulum akan mudah karena pola pikir guru telah terbentuk dan mempunyai kesiapan untuk menerima perubahan yang terjadi.

c. Guru sebagai pengembang kurikulum

Tugas guru bukan hanya mengajar di dalam kelas, melainkan juga sebagai pengembang kurikulum. Guru sebagai pengajar terbatas pada penyampaian bahan pelajaran kepada peserta didik, sedangkan guru sebagai pengembang kurikulum bertugas untuk mengembangkan dan memodifikasi bahan pelajaran dalam rangka menyesuaikannya dengan kondisi peserta didik dan lingkungannya. Untuk menjaga efektivitas pencapaian kurikulum, guru hendaklah terlebih dahulu memahami dan menghayati falsafah dan

8 Ahmad Zabidi Abdul Razak, Ciri Iklim Sekolah Inti: Implikasinya Terhadap Motivasi Pembelajaran. Jurnal Pendidikan, 2006. h.3. 
tujuan kurikulum, struktur dan organisasi kurikulum serta mata pelajarannya. Dengan demikian, khususnya guru di sekolah inti harus dapat memainkan berbagai peranan baik sebagai pengajar maupun sebagai pengembang kurikulum. Singkatnya, strategi implementasi kurikulum pada aspek guru yaitu mengubah mind set guru, membentuk budaya baru di lingkungan sekolah dan posisi guru sebagai pengembang kurikulum. Strategi tersebut mestinya terus diperbarui dan terlaksana secara berkelanjutan khususnya di sekolah inti dan sekolah yang menghendaki penyesuaian menurut tuntutan zaman.

\section{Bentuk Strategi Implementasi Kurikulum}

Dalam mengimplementasikan kurikulum terdapat beberapa kemampuan yang mesti dikuasai guru. Pertama, memahami esensi tujuan kurikulum, kedua menjabarkan tujuan kurikulum menjadi tujuanlebih spesifik dan ketiga, menerjemahkan tujuan khusus kepada tujuan pembelajaran. ${ }^{9}$ Kemampuan-kemampuan tersebut merupakan dasar untuk merumuskan bentuk strategi implementasi kurikulum. Bentuk strategi implementasi kurikulum meliputi dua program utama yaitu silabus dan Rancangan Pelaksanaan Pengajaran(RPP).

\section{a. Silabus}

Silabus merupakan kurikulum operasional yang lebih detail untuk membelajarkan peserta didik. Silabus adalah suatu rencana pembelajaran terperinci untuk satu mata pelajaran yang dijadikan panduan dalam proses pembelajaran. ${ }^{10}$ Silabus merupakan kurikulum yang secara langsung digunakan untuk memberikan perlakuan terhadap kelompok belajar peserta didik dan dalam kondisi tertentu. ${ }^{11}$

Silabus sangat penting sebagai rujukan bagi guru dalam proses pembelajaran karena silabus memuatbahan pelajaran yang perlu disampaikan padajangka waktu tertentu. Sebagai rujukan, maka silabus mesti dirumuskan secara jelas baik mengenai bahannya maupun konstruksinya. Silabus harus dapat diimplementasikan dengan pasti dan dapat meningkatkan kualitas proses dan hasil pembelajaran secara berkelanjutan. Sekolah yang

\footnotetext{
${ }^{9}$ Rusman, Manajemen Kurikulum. Edisi ke-2. (Jakarta: Rajawali Press. 2009). h.75

${ }^{10}$ Dakir, Perencanaan dan Pengembangan Kurikulum. Cetakan ke-2 (Jakarta: Rineka Cipta. 2010). h. 142

${ }^{11}$ Muhaimin, dkk. Pengembangan Model Kurikulum Tingkat Satuan Pendidikan pada Sekolah dan Madrasah. Edisi I. (Jakarta: Rajagrafindo, 2009). h. 111
} 
sukses secara komprehensif yaitu sekolah yang dapat membantu peserta didik makin hari makin memperoleh kualifikasi yang lebih tinggi. ${ }^{12}$

Khususnya di sekolah inti, silabus mestinya adalah susunangurubaik secara sendirisendiri maupunberkelompok dengan guru lainnya. Mereka adalah sosok akademik yang mempunyai kraf.Kraf adalah sesuatu yang unik dan dimiliki sebagai suatu keterampilan guru. Kraf juga dipahami sebagai keterampilan praktis kreativitas guru. ${ }^{13}$ Kraf yang tinggi akan menghasilkan silabus sesuai kriteria. Kriteria silabus yang baik mampu menjawabempat pertanyaan yaitu(1) kompetensi apakah yang harus dimilikipeserta didik setelah melalui proses pembelajaran?, (2) materi apa yang mesti dipelajari peserta didik berkaitan dengan kompetensi yang hendak dicapai?, (3) bagaimana cara yang dapat dilakukan peserta didik agar kompetensi tersebut dapat tercapai dan(4) bagaimana mengetahui bahwa pelajar telah memahami kompetensi tersebut? ${ }^{14}$

Keempat pertanyaan di atas merupakan suatu sistem yang elemen-elemnnya saling berkait dan saling mendukung. Pertanyaan pertama merujuk kepada tujuan pembelajaran. Tujuan pembelajaran dapat dicapai setelah memeroses materi pelajaran (pertanyaan ke dua). Sebaliknya, materi pelajaran menjadi bahan olahan untuk mencapai tujuan. Pertanyaan ke tiga, merujuk kepada strategi dan metode pembelajaran. Penggunaan strategi dan metode yang tepat akan memudahkan pencapaian tujuan. Sementara pencapaian tujuan dapat dipahami setelah melalui evaluasi (pertanyaan ke empat). Singkatnya, pencapaian tujuan yang efektif menjadi dasar sekaligus petunjuk arah dalam proses pembelajaran.

\section{b. Rancangan Pelaksanaan Pengajaran (RPP)}

Rancangan Pelaksanaan Pembelajaran (RPP) merupakan turunan dari silabus sebagai dokumen perencanaan pembelajaran yang lebih spesifik. RPP merupakan panduan harian guru dalam proses pengajaran dan pembelajaran untuk mencapai kompetensi yang telah ditetapkan. Perencanaan pembelajaran merupakan langkah terpenting dalam suatu proses pembelajaran yang sistematis. Dengan perencanaan yang baik, pola tindak mengajar guru dapat terselenggara secara sistematik sesuai dengan kondisi yang dihadapi.

12 Millar. A Comprehensive Future: Quality and Equality for Our Children. London: Compass (www.compassonline.org.uk.Diakses pada 23 Agustus 2010, 2006)

${ }^{13}$ Salleh,Pemikiran Profesional Keguruan terhadap Kurikulum dan Pengajaran. (http://www.salleh@ums.edu.my. Diakses pada 19 Agustus 2010, 2009).

${ }^{14}$ Lot cit,Muhaemin, dkk. h.113. 


\section{Strategi Pembelajaran di Sekolah}

Berbagai strategi pembelajaran yang dapat dirancang oleh guru dalam upaya mengembangkan strategi belajar peserta didik. Dalam tulisan ini dikemukakan dua strategi pembelajaranyaitu Strategi Model O’Mallay dan Chamot dan Strategi Model Oxford. Untuk lebih jelasnya diuraikan sebagai berikut:

\section{a. Strategi Model O'Malley dan Chamot}

Strategi pengajaran model O’Malley dan Chamot (1994) berdasarkan teori kognitif dan hasil penyelidikan strategi pembelajaran bahasa kedua. Model ini disebut CALLA (The Cognitive Academic Language Learning Approach). Melalui program CALLA, strategi pembelajaran yang baru akan diperkenalkan dan strategi yang sudah digunakan oleh peserta didik akan dilanjutkan. Melalui cara ini, peserta didik berpeluang untuk menggunakan strategi pembelajaran dalam situasi yang sebenarnya.

Program CALLA mempunyai lima tahapan, antara lain:

\section{1) Tahapan Persiapan}

Tahap, pertama ini merupakan masa meletakkan dasar yang kuatuntuk mengembangkan pembelajaran berpusatpeserta didik. Beberapa elemen yang perlu diperhatikan dalam tahap ini antaranya adalah mewujudkan suasana ruang kelas yang berpusat peserta didik, mengembangkan efikasi diri dalam menerapkan strategi yang biasa digunakan peserta didik. ${ }^{15}$ Efikasi diri sungguh pentingbagi peserta didik untuk meningkatkan kepercayaannya bahwa mereka dapat melaksanakan tugas dengan baik. Dengan efikasi ini, peserta didik akan termotivasi secara instrinsik dalam belajar. Mereka berusaha dengan gigih, tahan dalam menghadapi tantangan dan merasa puas dengan keberhasilan yang diraih Sebaliknya, peserta didik yang mempunyai tahap efikasi diri yang rendah yaitu mereka lemah,tidak mampu memeroses pembelajaran dengan baik, tidak melakukan sesuatu yang menantang dan tidak energikdalam berusaha. Oleh karena itu, pengembangan efikasi diri pada masa persiapan adalah penting karena penggunaan strategi pembelajaran yang diharapkan akan membawa keberhasilan.

Manakala peserta didik mengetahui tanggung jawab mereka dalam pembelajaran dan dapat menilai diri bahwa mereka akan belajar, maka mereka dianggap telah bersedia untuk memulai pembelajaran. Seterusnya, guru membimbing peserta didikuntuk

${ }^{15}$ Chamot et al. The CALLA handbook: Implementing the Cognitive Academic Language Learning Approach. (New York: Pearson Education,1994), h. 83-84. 
membentuk strategi pembelajaran yang biasa mereka lakukan sepanjang proses pembelajaran berlangsung. Aktivitas ini dapat dilakukan dengan wawancara, diskusi, angket dan jurnal harian peserta didik. Mengenali strategi peserta didik dalam belajar dapat membantu guru dalam menentukan strategi pembelajaran yang lebih sesuai.

2) Tahapan Pemaparan

Penerapan strategi pembelajaran akan menjadi lebih efektifapabila dilakukan secara jelas dan disertai dengan perbandingan-perbandingan yang sesuai. Sebaik-sebaik strategi yang dilakukan guru yaitu menerangkan kepentingannya, metode, memberitahu waktu yang sesuai dan meminta peserta didik mempersoalkan pengalaman sepanjang mereka dalam proses pembelajaran.

Guru perlu memperjelas dan menunjukkan strategi yang hendak dilakukan peserta didik. Apa yang seharusnya dilakukan peserta didik, guru berkepentingan menjelaskannya. Guru menjelaskan secara pasti dan berkesan, bukan sekedar menyampaikan begitu saja. Penyampaian informasi yang jelas, sistimatis, dan terukur, merupakan syarat efektifnya suatu informasi. Oleh karena itu, guru harus dapat memastikan apa yang sebenarnya harus dilakukan peserta didik? bagaimana peserta didik mengerjakannya? Dengan siapa peserta didik menyelesaikannya? Di mana peserta didik melakukannya? Dan pertanyaan serupa yang mendukung efektifnya pemaparan.

3) Tahapan Latihan

Tingkat paling penting dalam pembelajaran adalah peserta didik berlatih dengan menggunakan strategi belajar yang disenanginya dan membangun pemikiran strategik. Lantaran itu, startegi pembelajaran yang diterapkan guru senantiasa dapat memotivasi peserta didik untuk mengembangkancara pelajar, berpikir, dan menampilkan strategi belajarnya secara maksimal. Kondisi ini dapat dicapai melalui proses latihan secara sistimatis, terukur, dan berkelanjutan.

Guru perlu memberi kesempatan kepada peserta didik untuk menggunakan strategi belajar yang lebih mudah dan realistik sesuai dengan lingkungannya. Pembelajaran melalui radio, TV, komputer, android, swa-akses, online dan semacamnya lagi memungkinkan peserta didik dapat belajar tanpa banyak bergantung kepada guru. Kreativitas dan keterampilan berpikir mereka perlu dibangun karena kreativitas dan keterampilan berpikir sangat diperlukan peserta didik. Dengan terbangunnya kedua elemen 
tersebut, peserta didik merasa lebih bebas dalam menyusun buah pikiran sesuaidengan tujuan masing-masing.

Pembelajaran yang efektif dapat mendorong peserta didik untuk mengkreasi pembelajaran berdasarkan pikiran mereka secara individu ataupun berkelompok. Guru mesti memberi pujian dan menunjukkan pengakuan serius bahwa strategi yang digunakan peserta didik adalah lebih efektif dan berhasil. Di samping itu, guru penting pula memberi motivasi bagi mereka yang belum berhasil dengan menyarankan menggunakan strategi lain yang mungkin dapat membantu mendapatkan hasil kerja yang lebih baik.Namun, guru tidak semestinya menetapkan pola yang harus diterapkan oleh peserta didik. Strategi guru dalam hal ini adalah mempermudah peserta didik dalam menyelesaikan tugas. Justeru guru hendaknya menganalisis pendekatan yang sesuai dengan peserta didik yang fluralistik. ${ }^{16}$

4) Tahapan penilaian

Pada dasarnya, penilaian tidak hanya ditujukan kepada peserta didik, tetapi juga kepada guru. Guru perlu menilai strategi pembelajaran yang ia terapkan apakah strategi tersebut dapat memudahkan peserta didik dalam belajar ataukah justeru menyusahkan mereka untuk mencapai tujuan. Ada anggapan dari sebagian guru bahwa penilaian adalah tanggung jawab guru semata-mata dan merupakan ekslusif bagi guru bersangkutan. Sekiranya anggapan ini masih menjadi mind set guru, maka anggapan itu harus bergeser kepada penilaian yang mengedepankan penilaian diri peserta didik.

Penilaian diri "self assessment" adalah suatu teknik penilaian di mana peserta didik diminta untuk menilai dirinya sendiri berkaitan dengan status, proses, dan tingkat pencapaian kompetensi yang dibahas. dapat dilakukan dengan menerapkan daftar pertanyaan atau angket, wawancara, dan jurnal harian. Otentitas, kemandirian, dan penerapan nilai-nilai moral bahkan dapat terbentuk dengan sendirinya melalui penilaian diri peserta didik. Kegiatan penilaian diri sendiri dapat meningkatkan rasa bertanggung jawab terhadap pembelajaran yang dialami dengan kepercayaan yang sangat tinggi. ${ }^{17}$

Kelima tahap strategi pembelajaran yang dikemukakan oleh O’Malley dan Chamot di atas adalah saling berkaitan satu dengan lainnya. Misalnya, padatahap persiapan, guru

\footnotetext{
${ }^{16}$ Noraza Ahmad Zabidi. Pembelajaran bahasa secara autonomi: Sejauh manakah bahan pengajaran menyediakan pelajar? Prosiding. Strategi Pengajaran Kepelbagaian Pelajar. Selangor. Fakulti Pendidikan, UKM.2000.h.265

${ }^{17}$ Abdou Ndoye. Peer/Self Assessment and Student Learning International. Journal of Teaching and Learning in Higher Education, 2017. Vol 29 Number 2 ,h..259
} 
dapatmenggali strategi yang sering digunakan peserta didikuntuk tugas tertentu. Kemudian, berpindah ke tahap pemaparan untuk menunjukkan strategi baru yang dapat digunakan pada tugas yang sama. Selepas itu, guru dapat saja kembali ke tahap persiapan untuk mendapatkan informasi baru daripeserta didik. Bagan 4.1 menggambarkan kaitan antara kelima tahap strategi pembelajaran.

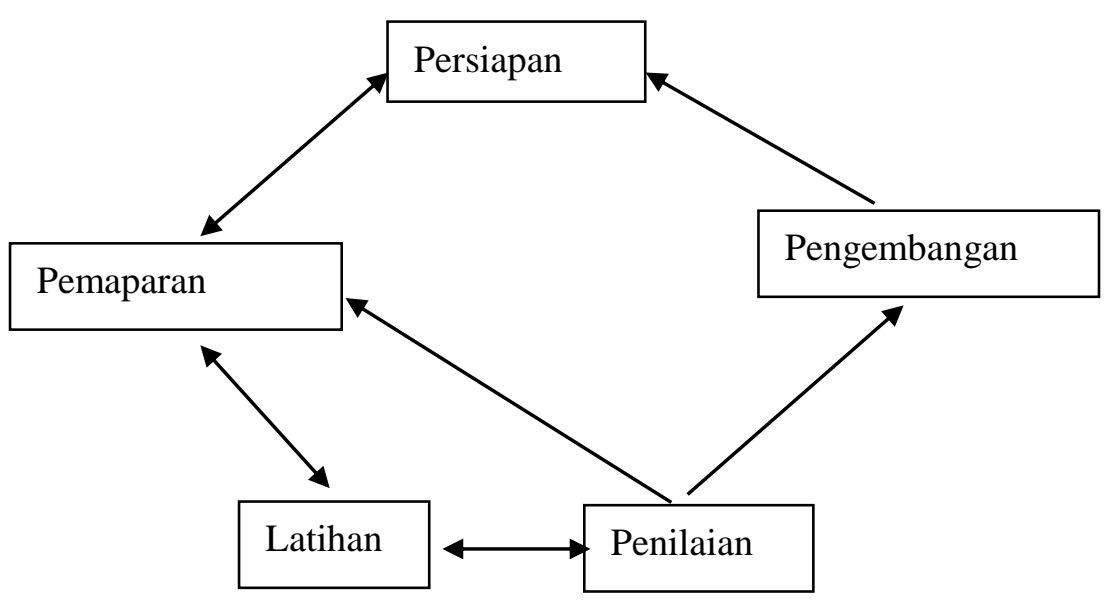

Bagan 4.1 Model Strategi Pembelajaran (adaptasi dari O’Malley dan Chamot (1999)

Dalam melaksanakan model tersebut di atas, peranan guru dalam proses pembelajaran berawal dari pemegang kendali dan tanggung jawab yang lebih banyak, kemudian berangsur-angsur peserta didik mengambil alih tanggung jawab tersebut. Namun, pengambilalihan tersebut tidak sampai menjadikan peranan guru menjadi mudah dan ringan. 
Untuk lebih jelasnya, kerangka kerja strategi pembelajaran ditampilkan dalam Bagan 4.2 berikut ini. $^{18}$

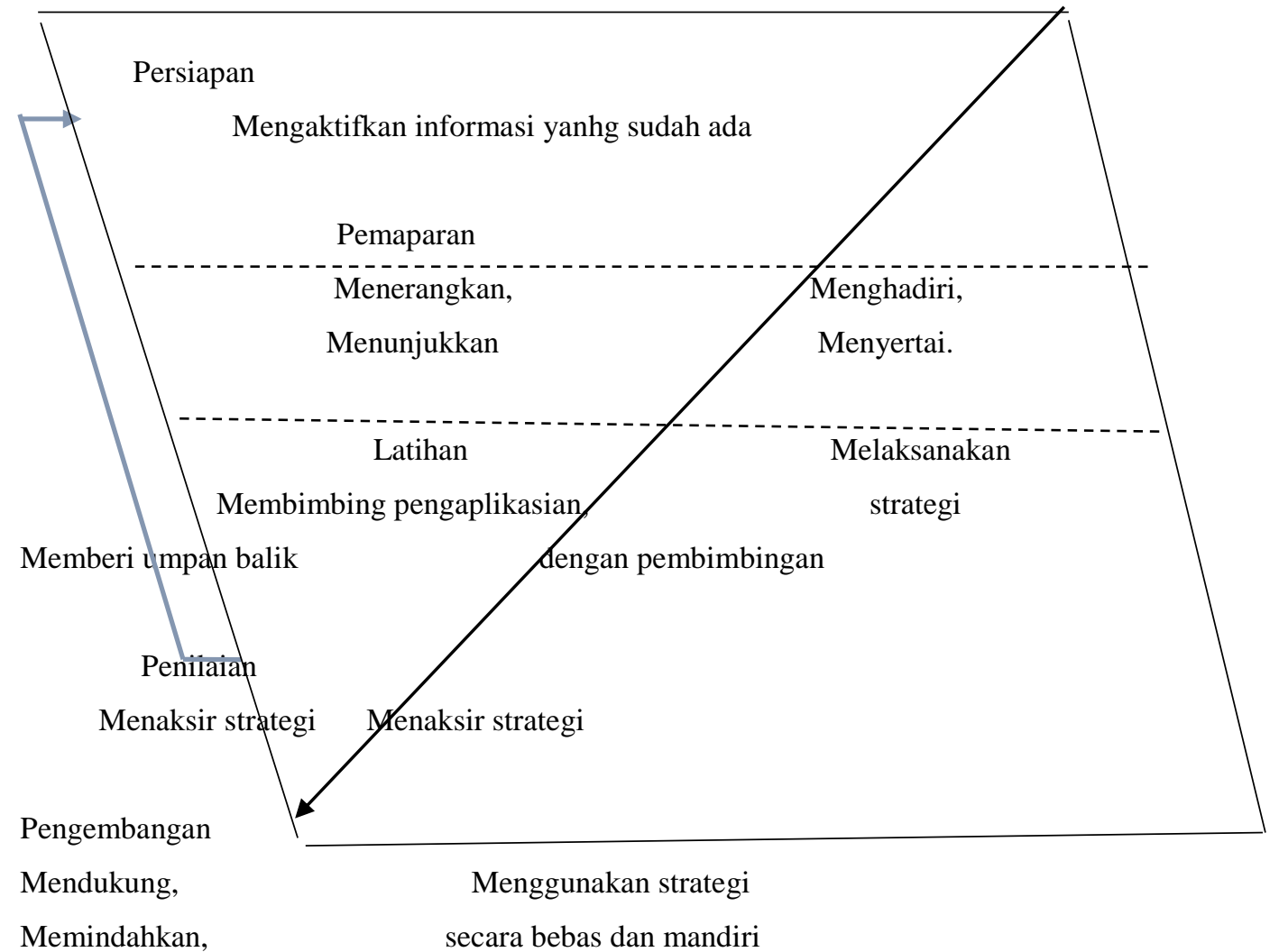

Memindahkan strategi ke dalam tugas baru

Bagan 4.2 Kerangka kerja strategi pembelajaran (Adaptasi dari Chamot dan O’Malley 1994).

Berdasarkan bagan di atas, tampak bahwa aktivitas peserta didik dalam proses pembelajaran makin lama akan menjadi peserta yang aktif, bebas dan mandiri. Tetapi, tidak berarti bahwa guru keluar dari siklus pembelajaran yang berlangsung.

\section{b. Strategi Model Oxford}

Model strategi pembelajaran yang dikembangkan oleh Oxford adalah sangat tepat untuk mata pelajaran bahasa, namun dapat juga menjadi inovasi dalam mata pelajaran lain. Sebab, cocok digunakan untuk program jangka panjangdan juga jangka pendek dengan memilih strategi-strategi tertentu.Model ini terdiri atasdelapan langkah. Lima langkah pertama merupakan langkah perencanaan dan persiapan, dan tiga langkah

18 Oxford. Language Learning Strategies: Methods, Findings, and Instructional Implications. The Modern Language Journal. 73 (4). 1989. h. 405. 
lainnyamelibatkan kerja mengendalikan, menilai dan memperbarui program. Setiap langkah tidak semestinya dilakukan menurut urutan, tetapidapat dilakukan pada waktu yang sama dengan sedikit perubahan urutan.

Delapan langkah strategi pembelajaran diuraikan sebagai berikut:

1) Memahamikebutuhanpeserta didik dan penjatahan waktu

Guru perlu mengenali latar belakang kehidupan peserta didik. Misalnya, bagaimana keterampilandalam berkomunikasi? Apakah kebutuhan mereka perlu dipenuhi agar mereka dapat menggunakan srategi pembelajaran secara efektif? Apakah waktu yang digunakan itu cukup memberi manfaat sesuai dengan kompetensi yang diharapkan kurikulum?

2) Memilih strategi yang sesuai

Guru memilih strategi pembelajaran yang dapat memenuhi kebutuhan peserta didik, sesuai dengan potensi dan karakter mereka. Untuk itu,sangat tepat apabila seorang guru menguasai varian strategi agar dapat mengakomodasi perbedaan gaya dan cara peserta didikbelajar. Namun, perlu diingat bahwa tidak satu pun strategi yang paling baik apabila strategi tersebut berdiri sendiri.

3) Mengintegrasikan latihan

Kepentingan mengintegrasikan program latihan adalah strategi yang memudahkan peserta didikmenghubungkan program pembelajaran dengan strategi belajar yang ditempuh. Guru harus mampu mengintegrasikan antara tujuan, bahan dan tugas.

4) Memerhatikan isu motivasi

Guru perlu memerhatikan isu-isu yang dapat meningkatkan motivasi belajar peserta didik. Berbagai cara yang dapat dilakukan guru yaitu (a) penjelasan pentingnya dan manfaat penggunaan strategi tertentu, (b) pemberian pujian dan gred dan (c) memberi kesempatan kepadapeserta didik untuk memilih sendiri strategi yang hendak digunakan.

5) Menyediakan bahan dan aktivitas

Bahan pelajaran merupakan salah satu sarana yang dapat mengaktifkan strategi belajar peserta didik. Melalui bahan yang menarik dan sesuai dengan kemampuan peserta didik dapat menggiatkan peserta didik dalam belajar.

6) Mengendalikan latihan dengan informasi 
Keberhasilan strategi belajar peserta didik sangat bergantung pada penjelasan guru terutama dalam situasi baru. Penjelasan diiringi dengan latihan, latihan diiringi dengan penjelasan akan membuat pembelajaran lebih bermakna. Oleh karena itu, pelaksanaan latihan perlu diintensifkan untuk mengasah dan mengembangkan aspek motorik peserta didik.

7) Menilai program latihan

Pengamatan yang sementara dan setelah program latihan dilakukan sangat berarti bagi keberhasilan program tersebut. Komentar peserta didik selama proses pembelajaran dapat menjadi latihan dalam mengaplikasikan suatu strategi baru.

8) Meninjau dan memperbarui program

Setelah proses penilaian dilakukan, menghasilkan saran demi menambah baikkan dan memperbarui program. Langkah akhir ini memungkinkan kemba like langkah pertama dan boleh jadi mengulangi setiap langkah lagi dengan proses yang lebih cepat daripada siklus sebelumnya. ${ }^{19}$

Berdasarkan pembahasan di atas, maka seorang guru ketika mengajar tidak semestinya hanya mengandalkan kemampuan teoretik yang dimilki, tetapi juga memerhatikan cara dan kemampuan peserta didik dalam memeroses belajarnya. Justeru pembelajaran bisa gagal, apabila guru mengindahkan kemampuan peserta didik.

Implementasi kurikulum yang berhasil di sekolah sangat bergantung kepada kemampuan lokal yaitu motivasi, komitmen, kondisi internal sekolah dan keseimbangan antara kritik dengan dukungan. Implementasi bukan berarti melanjutkan tentang apa yang telah disepakati sebelumnya, tetapi suatu kegiatan diskusi dan transformasi disertaimotivasi, kepercayaan dan kemampuan individu. Terdapat tiga faktor yang dapat mempengaruhi implementasi kurikulum yaitu: (1) Karakteristik kurikulum, yang meliputi skop kurikulum, ide baru suatu kurikulum dan kejelasannya bagi pengguna di lapangan, (2) Strategi implementasi, seperti perbincangan profesi, seminar, lokakarya, penyediaan bukubuku dan kegiatan yang dapat memotivasi penggunaan kurikulum di sekolah (3) Karakteristik pengguna kurikulum, yang meliputi pengetahuan, keterampilan, nilai dan sikap guru terhadap kurikulum serta kemampuannya bagi merealisasikan kurikulum dalam pembelajaran $^{20}$

\footnotetext{
${ }^{19}$ Lot cit Oxford. h. 408-410.

${ }^{20}$ Lot cit' Rusman, h.74
} 
Faktor yang memengaruhi implementasi kurikulum yaitu dukungan: kepala sekolah, rekanguru dan internal seorangguru. Guru merupakan faktor penentu karena bagaimanapun baiknya sarana pendidikan,apabila guru tidak mampu mengajar dengan baik, maka hasil pembelajaran tidak akan efektif. ${ }^{21}$ Sementara itu, pengalaman dan keterampilan guru sangat penting dan berpengaruh terhadap keberhasilan implementasi kurikulum di sekolah. Bagaimanapun apiknya sebuah kurikulum, kalau dijalankan oleh guru yang kurang profesional, maka kurikulum yang apik itu tidak berarti apa-apa dalam pencapaian tujuan. ${ }^{22}$

\section{KESIMPULAN}

Wujud kurikulum sebagai salah satu bidang inovasi pendidikan di Indonesia membawa perubahan yang berdampakpada konsep dan implementasinya. Guru perlu mengubah strategi pembelajaran konvensional ke strategi modern yang berdimensi multimedia. Pemanfaatan multimedia di sekolah inti adalah sesuatu yang mesti dilakukan. Strategi efektif dalam mengimplementasikan kurikulum sekolah adalah berorientasi kepada guru yang meliputi mengubah mind-set guru, membentuk budaya baru di lingkungan sekolah dan mengembangkan kurikulum.

Dalam mengimplementasikan kurikulum guru perlu menyusun silabus dan RPP sebagai panduan operasional dalam mengajar. Strategi pembelajaran tersebut meliputi tahap persiapan, pemaparan, latihan, penilaian dan pengembangan. Selain itu, dalam menerapkan strategi pembelajaran, guru perlu mengenal kebutuhan peserta didik, memilih strategi, mengintegrasikan latihan strategi, meotivasi, menyediakan bahan dan kegiatan, mengendalikan latihan, menilai program dan memperbarui program. Strategi guru mengimplementasi kurikulum dapat berpengaruh terhadap strategi belajar peserta didik. Peserta didik perlu diberi kesempatan untuk menentukan sendiri strategi belajarnya agar mereka dapat mencapai tujuan dengan mudah.

\footnotetext{
${ }^{21}$ Colin J-Marsh, George Willis.Curriculum: Alternative Approaches, Ongoing Issue, Third Edition (Columbus: Merrill Prentice Hall,2003), h. 236.

${ }^{22}$ Nancy B. Hertzog, Thecreation of a school and curriculum reform, Journal of Curriculum Studies, 29 (2), 1997. h. 218.
} 


\section{DAFTAR RUJUKAN}

Ahmad Zabidi Abdul Razak. 2006. Ciri Iklim Sekolah Inti: Implikasinya Terhadap Motivasi Pembelajaran. Jurnal Pendidikan (31): 3-19.

Benn, Melissa \& Millar, Fiona, 2006. A Comprehensive Future: Quality and Equality for Our Children. London: Compass (www.compassonline.org.uk. (23 Ogos 2010).

Chamot,A.U.\&O'Malley, J.M.1994. The CALLA handbook: Implementing the cognitive academic language learning approach. New York: Pearson Education.

Dakir. 2010. Perencanaan dan Pengembangan Kurikulum. Cetakan ke-2. Jakarta: Rineka Cipta.

Hertzog, Nancy B. 1997. The creation of a school and curriculum reform. Journal of Curriculum Studies. 29 (2): 209-231.

Marsh, Colin J \& Willis, George. 2003. Curriculum: Alternative Approaches, Ongoing Issues. Third Edition. Columbus: Merrill Prentice Hall.

Mok Soon Sang. 2010. Falsafah Pendidikan, Kurikulum dan Profesionalismne Keguruan. Selangor: Penerbitan Multimedia SDN.BHD.

Muhaimin, dkk. 2009. Pengembangan Model Kurikulum Tingkat Satuan Pendidikan pada Sekolah dan Madrasah. Edisi I. Jakarta: Rajagrafindo.

Mulyasa, E. 2006. Menjadi Kepala Sekolah Profesional. Cetakan ke-8. Bandung: Remaja Rosdakarya.

Noraza Ahmad Zahidi. 2000. Pembelajaran bahasa secara autonomi: Sejauh manakah bahan pengajaran menyediakan pelajar? Prosiding. Strategi Pengajaran Kepela bagaian Pelajar. Selangor. Fakulti Pendidikan, UKM.

Ndoye, Abdou.2017. Peer/Self Assessment and Student Learning. International. Journal of Teaching and Learning in Higher Education,. Vol 29 Number 2.

O’Malley, J.M. \& Chamot, A.U. 1990. Learning Strategies in Second Language Acquisition. Cambridge: Cambridge Universiti Press.

Oxford, R.L. \&Crookall. 1989. Language learning strategies: Methods, findings, and instructional implications. The Modern Language Journal. 73 (4): 404-419

Rusman. 2009. Manajemen Kurikulum. Edisi ke-2. Jakarta: Rajawali Press.

Salleh. 2009. Pemikiran Profesional Keguruan terhadap Kurikulum dan Pengajaran. http://www.salleh@ums.edu.my. (19 Ogos 2010). 
Sukmadinata, Syaodih Nana. 2010. Pengembangan Kurikulum: Teori dan Praktek. Cet. ke-13. Bandung: Remaja Rosdakarya.

Thorburn, Malcolm. 2007.Seizing the Moment: Improving curriculum and pedagogy prospects for physical education in Scotland. Symposium Journal. 49 (3).

Toh, K.A; K.C.Yap; S.Lee, S.V. Springham \&P.chua. 1996. Developing curriculum in Singapore: teacher-academic partnerships.Journal of Curirculum Studies. 28 (6): 683-697.

Undang-Undang Nomor 20 Tahun 2003 tentang Sistem Pendidikan Nasional. 